\title{
FISCAL AND NON-FISCAL DETERMINANTS BEHIND THE CREATION OF NEW WORK PLACES IN THE PRIVATE SECTOR - A REVIEW OF CHOSEN AREAS
}

\author{
FISKALNE I POZAFISKALNE DETERMINANTY TWORZENIA NOWYCH MIEJSC \\ PRACY W SEKTORZE PRYWATNYM - PRZEGLĄD WYBRANYCH OBSZARÓW
}

https://doi.org/10.34739/zn.2019.48.07

Anna Milewska

Poland, Warsaw University of Life Sciences, Faculty of Economic ORCID: 0000-0003-4776-6049, e-mail: anna_milewska1@sggw.pl

\begin{abstract}
The author of this article presents fiscal and non-fiscal factors that determine the creation of new work places in the private sector. To help explain this topic it was important to study the legal acts and available literature as well as use of other qualitative theoretical methods such as: analysis, synthesis, comparison, generalization, deductive and inductive reasoning methods. This resulted in distinguishing public levies which are significant to determine the costs of employment. These costs mainly include contributions to the pension (retirement insurance, disability insurance premium and work accident insurance) as well as to the Labour Fund. In the following part the author presents the specifics of the human and social capital, employee's competencies, globalisation and generational differences that impact the current job market. The outcome of this study concludes that employment costs have remained fairly stable for the last few years (the last major increase of employment contributions took place in 2012). Nonetheless, a growing scarcity of human resources, especially generation $\mathrm{Y}$, has become the biggest challenge.
\end{abstract}

Keywords: public levies, costs of employment, competencies, generation $\mathrm{Y}$

Streszczenie: W artykule tym autorka przyjęła za cel wskazanie fiskalnych i pozafiskalnych uwarunkowań związanych z tworzeniem nowych miejsc pracy w sektorze prywatnym. Pomocne w realizacji tego celu było studium aktów prawnych i literatury a także pozostałe metody teoretyczne: analiza, synteza, porównanie, uogólnienie, metody wnioskowania indukcyjnego i dedukcyjnego. Wynikiem badań było wyodrębnienie danin publicznych mających znaczenie w określeniu kosztów zatrudnienia pracownika. Należą do nich przede wszystkim składki z tytułu ubezpieczenia emerytalnego, rentowego i wypadkowego oraz składka na Fundusz Pracy. Następnie ukazano specyfikę kapitału ludzkiego i społecznego, kompetencji pracowników, globalizacj i różnic pokoleniowych mających znaczenie dla obecnego rynku pracy. Wnioski z przeprowadzonych badań dowodzą, iż koszty zatrudnienia pracownika od kilku lat pozostają na względnie stabilnym poziomie (największe zmiany związane z podwyższeniem składki na ubezpieczenie rentowe miały miejsce w 2012 r.) Wyzwaniem staje się natomiast dostępność kadry, głównie pokolenia $\mathrm{Y}$, która miałaby odpowiadać na rosnące zapotrzebowanie rynkowe i to w perspektywie długoterminowej.

Słowa kluczowe: daniny publiczne, koszt zatrudnienia, kompetencje, pokolenie $Y$

\section{Introduction}

The creation of new work places is of particular importance for the functioning of the economy, regional and local communities as well as for people directly seeking employment. Human work is the special kind of human activity that produces cultural goods, material goods or services. In modern societies, having a job was an important component of the individual's sense of value (Pikuła, 2014, p. 7).

However, due to the changes in the political systems and functions fulfilled by the state or local government, the creation of jobs has also become a source of imposing public levies. This approach and the so-called "taxing" of the workplace is mainly aimed at implementing the fiscal function of finance. It is directly related to obtaining funds for the implementation of the tasks of the state or local government units. The importance of the financial stimulus function should also be considered here. Through groups of tax policy instruments (tax incentives, reliefs, exemptions) or insurance (creating rates), the state (or local government) is able to interfere in the functioning of individual 
Milewska A., FISCAL AND NON-FISCAL DETERMINANTS BEHIND THE CREATION OF NEW WORK PLACES IN THE PRIVATE SECTOR - A REVIEW OF CHOSEN AREAS, Zeszyty Naukowe Uniwersytetu Przyrodniczo-Humanistycznego w Siedlcach Nr 121, Seria: Administracja i Zarządzanie (48) 2019

business entities, encouraging or discouraging initiatives in this area. While tax issues do not directly affect the creation of a new workplace, the employer's insurance obligations are particularly measurable for him when calculating the costs of each new employee. That is why education, experience and competence become particularly important. Both in theory and in organizational practice, the belief that employees and their competences are the most important business assets is becoming more and more popular. Therefore, new jobs are created where these resources are available and, moreover, are subject to cyclical development. The term "competences" is understood here as skills, knowledge, social behaviour, certain aspects of self-perception, mental patterns, character traits, attitudes, and the way of feeling, thinking and acting (Dubois, Rothwell, 2008, p. 32). The next chapters of this article will therefore focus on the fiscal determinants of creation of work places. The scope has been set taking into account all legal and formal requirements. In terms of the non-fiscal factors the author focuses on those specific for the profile of contemporary society and requirements of the modern economy.

\section{Literature review}

In the light of the social and economic changes, the Polish economy is increasingly a knowledge-based economy, and this is related to the new role of human capital. J. Fitz-Enz (2001) writes, every investment in human capital results in propelling business processes implemented by the company, directing them towards achieving the assumed organizational goals. As the author notes, a key feature of human capital is its spontaneous growth, thanks to permanent learning and the acquisition of experience. The concept of human capital took shape in the 1960's. Quoting the PWN dictionary, it is a resource of knowledge, skills, health and vital energy, contained in every person and society as a whole, defining the ability to work, adapt to changes in the environment and the possibility of creating new solutions (PWN, 2017). Researchers of this issue note that the concepts of human capital and human resources, employees, are closely related. According to A. Sajkiewicz (1991, p. 59), it is the proper management of human resources that ultimately leads to the formation of the company's valuable human capital. A similar concept is also expressed by M. Armstrong (2008, p.18), writing that human resource management is an integral part of human capital management that would not exist without it. Thanks to this, human resources are beginning to be seen as strategic more than technologies. According to Lipka (2000, p. 16), the strategic importance of human resources ensures uniqueness of enterprises, which in turn translates into competitive advantage and innovativeness of the organization. Gołębiowska (2005, p. 8) presents several arguments confirming that people are the most valuable resource of any company. In her opinion, the productivity of employees determines the effectiveness of the enterprise, and the productivity of employees itself results from their abilities, experience, practical skills, knowledge, attitudes, goals and values, as well as personality traits and motivation to work. In addition, employees are able to solve within the organization not only those problems that they share, but also those whose causes are different, e.g. of a technical or technological nature. In addition to learning and improvement, people are also characterized by creativity and conceptual thinking (Häuberer, 2011). Thus, it enables both early perception of potential threats and taking advantage of emerging opportunities for the enterprise. On the other hand, business development and business growth of the organization translates into the creation of new jobs and strengthening the company's position on the market.

\section{Methodology and theoretical basis}

The purpose of this article was the analysis of the determinants of the creation of new work places. It has been fulfilled based on the legal acts, available literature of the subject of taxation and insurance law, public finance and human resources management. The author also used information available in industry reports and the experience of the people available on professional websites. The goal of the article was also achieved by an elemental and causal analysis as well as deductive and inductive reasoning.

Pursuant to article 217 of the Constitution of the Republic of Poland, imposing taxes, other public levies, specifying entities, objects of taxation and tax rates, as well as the rules for granting reliefs and redemptions as well as categories of entities exempt from taxes is provided by statute (Constitution of the Republic of Poland, 1997) in connection with the above provision, it can be proved that public levies should be understood as taxes and other levies. Due to the role that taxes play in the implementation of budget revenues, they have been distinguished as the superior category. The others are therefore to be complementary. After systemic changes, one of the first legal acts that 
regulated the domain of public finance was the Act of 26 November 1998 on public finance. According to its provisions (art. 3) public revenues included public levies (i.e. taxes and other cash benefits), as well as other revenues (including fees). This approach allowed, although to a limited extent, to develop the category of "public levies" and to indicate fees in this group. Reform of the public finance sector, introduced pursuant to the Act of 27 August 2009 meant that nowadays public revenues are: public levies, which include, among others:

- taxes,

- contributions,

- fees,

- profit payments from state-owned enterprises and sole proprietorships of the

Treasury and state-owned banks, as well as other cash benefits, which the obligation to incur for the benefit of the state, local government units, state special-purpose funds and other units of the public finance sector, results from separate acts.

There are no legal definitions of public tribute in other normative acts. Relating to subsequent laws can only complicate attempts to determine the meaning of the concepts analysed here (Krzywoń, 2011 , p. 31). Given the nature and fiscal significance in the Polish system of mandatory financial charges, four groups of charges can be distinguished (Poszwa, 2007, p. 5):

- taxes,

- contributions,

- fees,

- para-taxes.

The tax is a benefit of a public law, gratuitous, forced and non-returnable nature. It is implemented for the benefit of the Treasury, voivodship, poviat or commune and results from the tax act. The obligation to pay to the public authority (budget) is the first feature of the tax resulting from its purpose: taxes were created so that the public authority receives income from the taxpayer (Modzelewski, 2005 , p. 16). The gratuitous nature of this tribute is related to the lack of any equivalent benefit. Therefore, the payment of the tax does not involve the receipt of an individual mutual benefit from the public law association for the entity that has paid it. A characteristic feature of taxes is also their nonrefundability. The tax paid, as a rule, will not be refundable. An exception to this rule is the creation of e.g. overpayment (especially in the field of property taxes). This may occur when circumstances arise during the year that will result in the expiry of the tax liability and the tax calculated in proportion to the duration of the tax obligation has been paid in an amount higher than the amount due. It will then be refundable, if any, to its successor in taxation. The compulsory nature is manifested in the fact that the implementation of the obligation to pay it, resulting from the provisions of law or administrative decision of the authority, is secured by the authority of the state and eventual consequent actions by the public authority (Felis, 2012, p. 22). Individuals are therefore obliged to pay tax, under tax law or administrative decision of the relevant tax authority. If they fail to comply with this obligation (in the appropriate amount and time), then the entity entitled to collect this tribute has coercive measures and fiscal sanctions to enforce the overdue benefit.

Contributions are another group of public levies. Social security contributions will belong to those directly related to the creation of a new workplace, and thus also the employment of an employee. These contributions are not strictly tax charges, however, their weight is so significant in the conducted business activity that optimization of this cost should be, next to tax optimization, the domain of taxpayer's management (Szlęzak-Matusewicz, 2008, p. 158) The contributions qualified to the social insurance system include:

- retirement insurance,

- disability insurance premium contribution,

- sickness insurance contribution and

- work accident insurance contribution.

The division of insurance into four groups by type of protected risk returned together with the provisions of the Act of 13 October 1998 on the Social Insurance System The situation determining the creation, or not, of a new job by the employer are mainly costs related to social security. In accordance with applicable regulations, the burden of contributions applies to both the employee and the employer. They participate in the payment of the retirement and disability pension contributions. The full accident insurance contribution is paid by the employer (in 2019 between $0.67 \%$ and 3.33\%), while the health care insurance contribution is paid by the employee (details are shown in Figure 1). In this case, however, he plays the role of a payer, which means that he should calculate, collect and transfer all of the aforementioned contributions to the appropriate entity. In the event of the late settlement of these payments, the amount due will rise and, as a consequence, default interest will be charged. The basis for the calculation of these four types of contributions is the employee's income (gross salary). 
Milewska A., FISCAL AND NON-FISCAL DETERMINANTS BEHIND THE CREATION OF NEW WORK PLACES IN THE PRIVATE SECTOR - A REVIEW OF CHOSEN AREAS, Zeszyty Naukowe Uniwersytetu Przyrodniczo-Humanistycznego w Siedlcach Nr 121, Seria: Administracja i Zarządzanie (48) 2019

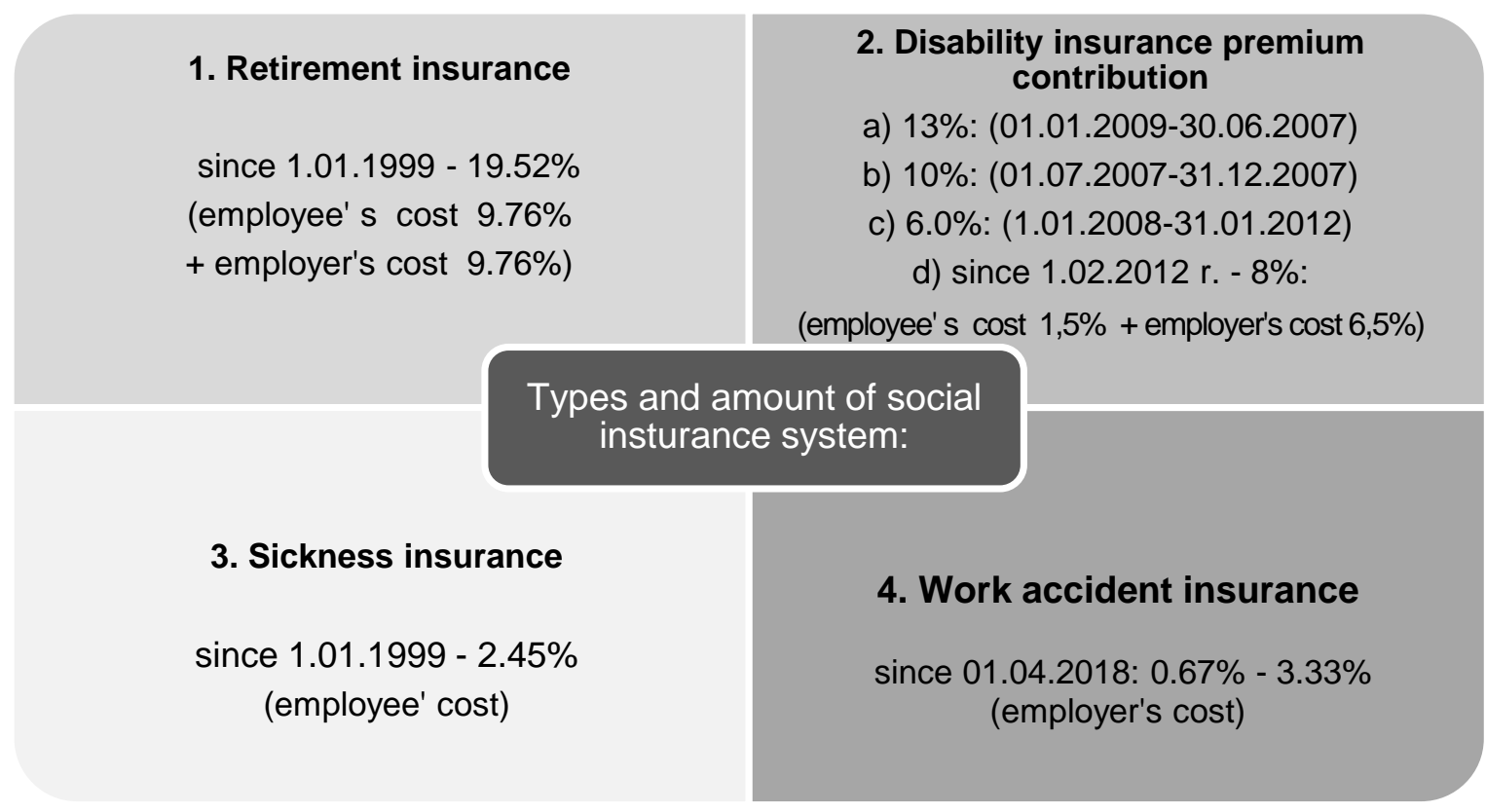

Figure 1. Organization and amount of social insurance system

Source: own study based on Act No. 887 of 13 October 1998 on the Social Insurance System Dziennik Ustaw, 1998-11-10, No. 137 (as amended).

At this point it's worth mentioning that for all employees, the employer is also obliged to pay the contribution to the Labour Fund (FP) $-2.45 \%$, a government fund established on 1 January 1990. Accumulated funds are used for the professional training of employees and the unemployed, internships, scholarships, cost refunds of the workplace for assigned unemployed or cost of professional preparation for adult employees. The employer is also required to pay $0.10 \%$ to the Fund of Guaranteed Employee Benefits (FGSP). The basis for the calculation both of these is the employee's income (gross salary).

Since January 2019, the minimum wage in Poland is 2250 PLN, which means that the employers will be required to plan for about 2800 PLN in their budget. The exact amount depends on the amount of accident insurance, depending on the type of work performed.

\section{Results and discussion}

In 2013, the Warsaw Institute for Educational Research conducted a survey of 941 Polish enterprises in the area of perception of employees' competences and competence management. According to the results, over $72 \%$ of the surveyed companies declared that employee competences (coded in the survey as knowledge, attitudes and skills) are the most important reflection of human capital. Formal qualifications of employees, confirmed by diplomas or certificates, formal education, health or personal culture were placed in subsequent, lower positions (Sienkiewicz, 2013, p. 37). The emphasis on the competences of employees in Polish companies makes them become a highly competitive and attractive resource compared to other countries, which in turn translates into the choice of Poland as a place for further investments and creation of new jobs. In addition, employees seek information about the economic situation of existing and emerging companies on the market and about their professional prospects (Domański, 1993, p. 32).

The concept of social capital was first used in 1916 by L.F. Hanifan. However, it only gained importance in the 1980's, when the works of P. Bourdieu and J. Coleman were published. They initiated a wide interest in social capital among representatives of various fields of science. Bourdieu's work (1986, p. 241-248) characterized social capital as built on social relationships, commitments and based on the reciprocity of interpersonal relations, which in certain conditions is convertible into economic capital and can be institutionalized in the form of social trust. The vision of achieving benefits leads to the creation of social bonds and encourages network participants to 
Milewska A., FISCAL AND NON-FISCAL DETERMINANTS BEHIND THE CREATION OF NEW WORK PLACES IN THE PRIVATE SECTOR - A REVIEW OF CHOSEN AREAS, Zeszyty Naukowe Uniwersytetu Przyrodniczo-Humanistycznego w Siedlcach Nr 121, Seria: Administracja i Zarządzanie (48) 2019

collective and solidary behaviour. Translating the definition proposed by the sociologist into market realities, it can be stated that in enterprises, social capital will be based on knowledge (intellectual capital), employee proactivity, their ability to create bonds and maintain the organization's contacts with the environment. Social capital in the organization is also the ability to create extensive networks of cooperation, both between employees and the company and the outside world (e.g. clients, contractors, partners, competition, legal advice, etc.). According to F. Fukuyama (1997, p. 20), the most important determinant of social capital is trust, which contributes to creating measurable economic value. In a short time, lack of trust can destroy social relationships, create conflicts, social isolation, spawn contempt for authorities and law, and enforce the need to rebuild the legal order. It follows that the lack or shortage of social capital within an enterprise can lead to a reduction in productivity, competitiveness and even a complete inhibition of the organization's growth (Baron, Armstrong, 2007, p. 7). Lack of trust also negatively affects the readiness to take business risks and reduces information openness.

Shaping and strengthening social capital in the organization will translate into the production of some form of social structure within the enterprise, as well as a sense of involvement of individuals in creating a network of connections "to the outside". This explains the organization's ability to innovate: social connections contribute to the reciprocity of online activities, while the network provides the basis for confidence, increases the willingness to take risks ("we are no longer alone") and innovative activities (Kaba, 2010). Networks facilitate communication, coordination and cooperation, as well as shape and strengthen the reputation of individual participants, which allows and facilitates group problem solving (Dyduch, Szczepankiewicz, Szczepankiewicz, 2001, 193). Nowadays, entrepreneurs learn to skilfully use, strengthen and develop such networks, as this builds a strong position of the organization, and on a macroeconomic scale - contributes to the economic growth of the whole country. Cluster structures are a good example of networking between enterprises in Poland. According to data from the Polish Agency for Enterprise Development "Clusters in Poland", there are 14 Special Economic Zones in our country, which allow entrepreneurs to conduct business activities on preferential terms, e.g. thanks to tax reliefs, preparation of specially developed areas, etc. A good example of a cluster structure is, for example, the Nutribiomed cluster in the Lower Silesian Voivodship. As the PARP catalogue states: the area of interest and activities of the cluster includes advanced technologies in food processing and biotechnology, cosmetics and pharmacy. Currently, the cluster consists of six universities, three business environment institutions and over thirty enterprises from the food, biotechnology and biomedical industries. Internationally, the NUTRIBIOMED Cluster cooperates with partners from, among others, Italy, Hungary, Austria and the Czech Republic (PARP, 2012, 8-13). To sum up, cluster initiatives not only contribute to increasing the competitiveness of enterprises and creating new jobs, but also strengthen Poland's position in the international arena.

The phenomenon of globalization in both macro and micro-economic contexts strongly influences the dynamics of economic development of countries in the world, and thus - creation of new jobs. In academia, the concept of globalization first began to appear in the 1980's. Globalization is identified with many processes and phenomena; hence it is difficult to systematize its definition. Two approaches to globalization have been adopted for further consideration. The first of them, after Zaorska (2002, 16-18), describes globalization through the features that can be attributed to this phenomenon: multidimensionality (it manifests itself in politics, economics and culture), market integration (e.g. financial markets) and connection with the progress of science and technology. A slightly different approach to globalization is adopted by Czerny (2005, 18-20), although it also defines the phenomenon through several different characteristics: globalization as internalization (i.e. intensification of international exchange and interconnection between entities), as universalism, that is, the spread of phenomena, customs or things throughout the world and globalization as westernisation or modernization, i.e. the impact of the American lifestyle with its symbols: CNN, Hollywood. Mc Donald's.

Globalization leads to a kind of "regrouping" of economic forces, both at the state level and in the global context. This is no longer a matter of the trade liberalization mentioned above, but it is increasingly about the emergence of global consumers and global consumption as well as global competition. Thanks to the use of internet technology, the market "lives" 24 hours a day around the world, connecting players from all continents in an international game (J.E. Stiglitz, $2004,28)$. This significantly increases the demand for various resources, as the markets are growing. Consumers' awareness is also increasing - having unlimited access to the media, they obtain information about products and services they did 
Milewska A., FISCAL AND NON-FISCAL DETERMINANTS BEHIND THE CREATION OF NEW WORK PLACES IN THE PRIVATE SECTOR - A REVIEW OF CHOSEN AREAS, Zeszyty Naukowe Uniwersytetu Przyrodniczo-Humanistycznego w Siedlcach Nr 121, Seria: Administracja i Zarządzanie (48) 2019

not know about before, and which are able to meet their needs. Consequently, additional labour must be involved in those places where the production of goods in demand is taking place.

Enterprises that quickly respond to emerging demand in terms of both production and attractive export offers become beneficiaries of globalization. An additional advantage of individual countries, including Poland in particular, are political considerations: a stable and transparent system of supporting foreign investments, the economic potential as well as a level of security and the possibility of providing it (e.g. in contrast to Germany, France or Great Britain, there are no acts of terrorism against civil citizens or at workplaces) (Dudek, 2010, 440). One example of a Polish company that has used the opportunities of shortening the global distance and thus creating the possibility of gaining new markets is Ursus. On March, 2017, the company signed a \$ 100 million contract with a Zambian company Industrial Development Corporation (IDC), committing to supply 2,694 tractors and 2506 pieces of other agricultural machinery (Business Insider Polska, PPP, 2017). Additionally, as part of the contract, an assembly plant will be built in the capital of Zambia, Lusaka, and 10 service points will be built throughout the country. This is the largest contract in the history of this company. In addition, the construction of the assembly plant at Lusaka is not only related to the fulfilment of the contract with IDC, but also involves the further expansion of Ursus - in accordance with the company's plans, it would also be a place from which the company could export equipment to other countries (Ogórek, 2017).

This is not the first success of the Polish manufacturer in Africa. Ursus signed its first contract four years ago, in 2013 - with Ethiopia. After two years, a proposal for another contract appeared - in 2015, in addition to further cooperation with Ethiopia, Ursus also signed a contract with Tanzania. Successes in these countries allowed for further expansion - a company originating from Namibia, Dobre Holding, bought from Ursus not only agricultural machinery, but also buses and special vehicles. Apart from Africa, the tractors of the Polish manufacturer are also exported to Iran. Thanks to these achievements, it was possible to develop the company itself and create many new jobs. Currently, Ursus has its factories in as many as three Polish cities: primarily in Lublin, but also in Dobre Miasto and Opalenica (Ogórek, 2017).

Another phenomenon related to globalization and resulting from its progress is the existence and intensive development of transnational corporations, whose subsidiaries are being created in new parts of the world, creating more jobs. Examples of such corporations present on the Polish market are General Electric, Royal Dutch / Shell Corporation or Toyota Motor Corporation. In addition to transnational corporations of an industrial nature, in the era of the knowledge economy, subsidiaries of modern corporations based on technologies and the Internet, such as IBM or Cisco System, also appeared in Poland. Unlike "traditional" industrial enterprises, modern corporations are flexible, do not have complicated and excessively extensive organizational structures, thanks to which they are able to respond quickly to market behaviour (Łoś - Nowak 2004, 40). Especially foreign investments, e.g. greenfield, or "from the ground up" are not only a source of new jobs, but also a channel for the transfer of modern technologies, a factor that increases the attractiveness of the region, as well as the investment attractiveness of the entire national economy.

\section{Conclusions}

There are many different determinants for creating new jobs in Poland. It is worth noting, however, that the Polish labour market is currently facing a situation where the tendency is reversed it is not the lack of jobs that is a challenge, but the shortage of workforce. The level of unemployment in Poland is at a record low; according to the payroll report of the recruitment company HAYS POLAND for 2017, most companies on the Polish market are expanding their structures and increasing employment, while experiencing a shortage of candidates. According to the organization's website, $93 \%$ of companies surveyed declare a desire to increase employment, while $90 \%$ of employers are aware of- and expect difficulties infinding employees (HAYS Wyzwania..., 2017). What's more, due to the growing number of jobs in our country, the challenge is not only to staff them, but also to retain existing employees in company structures, who, having a wide range of potential new jobs, change jobs faster than before. According to HAYS POLAND, every fourth Polish employee considered changing employment, within 6 months of the survey. Rotation applies to all job levels: from managers to junior specialists. In environments related to the area of human resources management, a statement was formed that the current situation in Poland can be called the "employee market".

One of the reasons for this is demographics. From year to year, the population of people of 
Milewska A., FISCAL AND NON-FISCAL DETERMINANTS BEHIND THE CREATION OF NEW WORK PLACES IN THE PRIVATE SECTOR - A REVIEW OF CHOSEN AREAS, Zeszyty Naukowe Uniwersytetu Przyrodniczo-Humanistycznego w Siedlcach Nr 121, Seria: Administracja i Zarządzanie (48) 2019

working age is decreasing in Poland, as well as the number of professionally active people. Fewer and fewer Polish people enter the labour market, and more and more leave it. According to data published by the "e-gospodarka" portal and based on research conducted by the Central Statistical Office, over the next decade, the number of people of working age in Poland will decrease by an average of $0.9 \%$ per year. If this forecast is maintained, in 2050 the labour market will lack about 10.5 million employees of working age, which will disturb the ratio to the number of people in a post-working age (eGospodarka, 2017).

Women's participation in the labour market is another challenge. Unfortunately, in Poland we can still observe a low level of professional activity of women. One of the main reasons is the difficulty in reconciling professional and private life, i.e. motherhood. Referring to the report of the HAYS POLAND company, entitled "Woman on the labour market 2017", about $65 \%$ of women encountered obstacles in their professional career, related to reconciling the sphere of parenthood with the performance of their work: no possibility to return to a previously held position, lack of flexible working hours, long working hours and taking work home, quick return to work after maternity leave, lack of work - life balance, etc. (Hays, Presja... 2017).

Generational differences between the employees themselves and their attitude to work are also becoming an important aspect. This is particularly evident in contemporary social dialogue about the "Y:" generation, i.e. "Millennials". The "Y" generation includes people born in the years 1980-1995 , who are currently of working age. Their advantage is a better education as compared to the generations of their parents (they were born after the political reform, in a democratic country with easy access to education), they are more familiar with the latest technologies, and thus self-confident and independent. On the other hand, they enter adulthood more slowly than their parents, becoming independent at a later age (e.g. they live in family homes up to 30 years of age and longer). This translates into a specific attitude to the labour market. Generation "Y" prefer flexible forms of employment or self-employment as freelancers, they highly value the balance between work and private life, mainly because they invest their free time in themselves and the implementation of their passions. The job they are looking for must meet several conditions: no overtime and / or flexible working hours, challenging projects, continuous professional development, and a partnership-based approach of employers towards employees. Lack of feedback, patronizing by superiors or a sense of underestimation lead to frustration and, consequently, to a change of job. Stability of employment ceases to be an "argument" or an asset of the employer; if the work does not bring satisfaction and does not allow development - the employee leaves, does not feel emotionally connected with the company. Therefore, older generations perceive such employees as ungrateful, spoiled and disloyal, which affects their openness to employing representatives of the "Y" generation (Nast 2017, 10-28).

To sum up, the current challenge of the Polish labour market is not the lack of new jobs, as their number increases every year, including due to the fiscal and non-fiscal determinants presented earlier. The challenge is the availability of staff that would respond to the growing market demand in the long term.

\section{References}

Legal Acts:

Konstytucja Rzeczypospolitej Polskiej z dnia 2 kwietnia 1997 r. (The Constitution of the Republic of Poland of 2 April, Journal of Laws 1997 no. 78, item 4830), art. 217.

Ustawa z dnia 29 sierpnia 1997 r. Ordynacja podatkowa (Dz.U. $1997 \mathrm{Nr} 137$ poz. 926 z późn. zm. (Act of 29 August 1997 Tax Code, Journal of Laws of 1997, No. 137, item 926 as amended).

Ustawa z dnia 13 października 1998 r. o systemie ubezpieczeń społecznych (Dz U. $1998 \mathrm{Nr}$ 887, poz. 137 z późn. zm.) Act of 13 October 1998 on the Social Insurance System (Journal of Laws 1998, No 887 item 137 (as amended)

Ustawa z dnia 26 listopada 1998 r. o finansach publicznych (Dz.U. 1998, Nr 155, poz. 1014 z późn. zm.) (Act 26 of November 1998 on public finance, Journal of Laws of 1998, No. 155, item 1014 , as amended).

Ustawa z dnia 27 sierpnia 2009 r. o finansach Publicznych (Dz.U. $2009 \mathrm{Nr} 157$ poz. 1240 z późn. zm.) (Act of 27 August 2009 on public finance, Journal of Laws 2009, No. 157, item 1240 as amended).

\section{Literature:}

Armstrong, M., Baron, A. (2008). Zarządzanie kapitałem ludzkim. Kraków: Oficyna Wolters Kluwer Business.

Armstrong, M., Baron, A. (2007). Human Capital Management. Achieving Added Value Through People. UK: Kogan Page Limited.

Bourdieu, P. (1986). The forms of capital, in: J.G. Richardson (ed.), Handbook of theory and research for the sociology of education. New York: Greenwood Press.

Czerny, M. (2005). Globalizacja a rozwój. Wybrane zagadnienia z geografii społeczno-gospodarczej świata. Warszawa: Wydawnictwo PWN. 
Milewska A., FISCAL AND NON-FISCAL DETERMINANTS BEHIND THE CREATION OF NEW WORK PLACES IN THE PRIVATE SECTOR - A REVIEW OF CHOSEN AREAS, Zeszyty Naukowe Uniwersytetu Przyrodniczo-Humanistycznego w Siedlcach Nr 121, Seria: Administracja i Zarządzanie (48) 2019

Domański, S. (1993). Kapitał ludzki i wzrost gospodarczy. Warszawa: Wydawnictwo PWN.

Dubois, DD., Rothwell, WJ. (2008). Zarządzanie zasobami ludzkimi oparte na kompetencjach. Od tradycyjnego działania kadr do współczesnego HR. Gliwice: Wydanictwo Helion.

Dudek, A. (2010). Globalizacja w stosunkach międzynarodowych, W: Współczesne stosunki międzynarodowe T. Łoś-Nowak (red.). Wrocław: Wydawnictwo Uniwersytetu Wrocławskiego.

Dyduch, W., Szczepankiewicz, M., Szczepankiewicz, E. (2001). Kapitał społeczny podstawą zdobywania przewagi konurencyjnej w Nowej Ekonomii, W: Strategie i konkurencyjność przedsiębiorstw po dziesięciu latach transformacji, M. Moszkowicz (red.). Polaniza Zdrój: Wydawnictwo Politechniki Wrocławskiej.

Felis, P. (2012). Elementy teorii i praktyki podatków majątkowych. Poszukiwanie ładu w opodatkowaniu nieruchomości w Polsce z perspektywy przedsiębiorców oraz jednostek samorządu terytorialnego. Monografie i Opracowania 588. Warszawa: Szkoła Główna Handlowa w Warszawie.

Fitz-Enz, J. (2001). Rentowność inwestycji w kapitał ludzki (pp. 73-75). Kraków: Oficyna Ekonomiczna, Dom Wydawniczy ABC.

Fukuyama, F. (1997). Zaufanie, Kapitał społeczny a droga do dobrobytu. Warszawa: Wydawnictwo Naukowe PWN.

Gołębiowska, G. (2005). Kadry i gospodarka zasaobami ludzkimi, W: Z. Gomółka (red.) Zarządzanie zasobami ludzkimi. Szczecin: Wydawnictwo Naukowe Uniwersytetu Szczecińskiego.

Häuberer, J. (2001). Social Capital Theory. Towards a Methodological Foundation. Heidelberg: Springer Fachmedien Wiesbaden $\mathrm{GmbH}$.

Kaba, A.J. (2010). Profile of contributors to the American Economic Review, in: Kaba, A.J. Human Capital Theory, Gender and Race. USA: Scientific Research Publishing.

Klastry w Polsce Wydanie 1 (2012). Polska Agencja Rozwoju Przedsiębiorczości (pp 8-13). Warszawa: Wydawnictwo PARP.

Krzywoń, A. (2017). Podatki i inne daniny publiczne w Konstytucji Rzeczpospolitej. Warszawa: Wydawnictwo Sejmowe.

Lipka, A. (2000). Strategie personalne formy. Kraków: Wydawnictwo Profesjonalnej Szkoły Biznesu.

Łoś-Nowak, T. (2004). O poszukiwaniu nowych form organizacji stosunków międzynarodowych w procesie gloablizacji. W: Problemy polityki bezpieczeństwa wobec problemów globalizacji, J. Świniarski, J. Tymanowski (red.). Toruń: Wydawnictwo Scholar.

Modzelewski, W. (red.) (2005). Wstęp do nauki polskiego prawa podatkowego, Wydanie szóste rozszerzene i zaktualizowane. Warszawa:
Instytut Studiów Podatkowych Modzelewscy i Wspólnicy.

Nast, M. (2017). Pokolenie JA, Niezdolni do relacji. Warszawa: Wydawnictwo Czarna Owca.

Pikuła. Norbert G. (red.). (2014). Marginalizacja na rynku pracy: Teorie i implikacje parktyczne. Kraków: Oficyna Wydawnicza Impuls.

Poszwa, M. (2007). Zarządzanie podatkami w małej i średniej firmie, rozwiązania na lata 2007-2009. Warszawa: Wydanictwo $\mathrm{CH}$ Beck.

Sajkiewicz, A. (1999). Strategia zmian w zasobach ludzkich W: A. Sajkiewicz (red.) Zasoby ludzkie w firmie. Warszawa: Wydawnictwo Poltext.

Sienkiewicz, Ł. (red.). (2013). Polityka zarządzania kompetencjami pracowników. Warszawa: Instytut Badań Edukacyjnych.

Stiglitz, J.E. (2004). Globalizacja. Warszawa: Wydawnictwo Naukowe PWN.

Szlęzak-Matusewicz, J. (2008). Zarządzanie podatkami. Warszawa: Oficyna Wydawnicza, Szkoła Główna Handlowa.

Zaorska. A. (2002). Ku globalizacji?, Przemiany w korporacjach transnarodowych i w gospodarce światowej (pp. 16-18). Warszawa: Wydawnictwo PWN.

Internet sources:

4 główne wyzwania rynku pracy, Pobrano z http://www.egospodarka.pl/143098,4-glownewyzwania-rynku-pracy, 1,39,1.html

Business Insider Polska, PAP (2017), Ursus z rekorodowym kontraktem. Kurs akcji spółki pionowo w górę. Pobrano z https://businessinsider.com.pl/ gielda/wiadomosci/ursus-sprzedaje-ciagniki-dozambii-i-otwiera-fabryke-w-afryce/1nldg82

Encyklopedia PWN, hasło: kapitał ludzki. Pobrano z https://encyklopedia.pwn.pl/haslo/kapitalludzki; 3920045.html (online: 01/12/2017).

Ogórek S. (2017), Ursus podpisał rekordowy kontrakt. Tysiące ciągników i maszyn pojadą do Zambii. Pobrano z https://www.money.pl/gospodarka/ wiadomosci/artykul/ursus-zambia-kontraktumowa,25,0,2283289.html.

Presja i wyzwania w pogodzeniu życia osobistego z zawodowym raport „Kobiety na rynku pracy 2017" Pobrano z https://www.hays.pl/notatkiprasowe-hays/presja-i-wyzwania-w-pogodzeniu$\%$ C5\%BCycia-osobistego-z-zawodowym-raport$\%$ E2\%80\%9Ekobiety-na-rynku-pracy2017\%E2\%80\%9D-1947787.

Wyzwania rynku pracy i plany pracodawców raport płacowy Hays Poland 2017, Pobrano z: https://www.hays.pl/notatki-prasowehays/wyzwania-rynku-pracy-i-planypracodawc\%C3\%B3w-raport-p\%C5\%82acowyhays-poland-2017-1821972. 